УДК 621.039 .56

DOI https://doi.org/10.32838/2663-5941/2021.3/19

\title{
Маловичко В.К.
}

Державний університет «Одеська політехніка»

\section{Брунеткін О.I.}

Державний університет «Одеська політехніка»

\section{ДОСЛІДЖЕННЯ АВТОМАТИЧНОЇ СИСТЕМИ РЕГУЛЮВАННЯ РІВНЯ ВОДИ В ГРУПІ ПІДІГРІВАЧІВ ВИСОКОГО ТИСКУ}

Система регенерації високого тиску є складовою частиною системи живильної води. Відповідно до класифікачї̈ технологічних систем, обладнання та трубопроводів за впливом на безпеку за «Загальними положеннями забезпечення безпеки атомних станиій» (ОПБ), підігрівачі високого тиску відносяться до систем нормальної експлуатації, важливих для безпеки.

Контроль рівня КГП забезпечує безаварійну роботу всього блоку. Система регенерації високого тиску призначена для підігріву живильної води, яка подається живильними насосами з деаераторів у парогенератори паром, частково відпраџьованих у проточній частині головної турбіни. Застосування ПВТ підвищує ККД установки і суттєво впливає на безпеку і надійність АЕС. Група ПВД підігріває воду, яка надходить у парогенератор, зменшуючи підігрів живильної води до кипіння, і тим самим зменшує кількість енергії, яка передається першим контуром для підігріву води до стану насичення. Для запобігання аварійним ситуачіям і для правильної роботи установки необхідно регулювати рівень конденсату в ПВД иляхом регулювання РК.

Підігрівач високого тиску являс собою вертикальний апарат поверхневого типу. Основними вузлами підігрівача є корпус і трубна система. Корпус складається з верхньої з'ємної частини і нижньої нерухомої частини.

Трубна частина складається із шести спіральних колон: трьох колекторів, щзо роздають, і трьох колекторів, що збирають, до яких приєднано горизонтальні змійовики, виконані у вигляді зварних спіралей. У нижній частині підігрівача до иих колекторів приєднані патрубки для підведення і відведення живильної води. Застосування ПВТ підвищує ККТ установки і суттєво впливає на безпеку і надійність АЕС. Для запобігання аварійним ситуаціям і для правильної роботи установки необхідно регулювати рівень конденсату в ПВТ шляхом регулювання рівня води.

Досліджено вплив регулюючого клапану на перехідний процес регулювання. Знайдено перетворення сигналу, що керує рівнем у підігрівачі високого тиску. Проведено експеримент на моделі теплового пункту в середовищі Simulink. Результати експерименту проаналізовано.

Ключові слова: регулюючий клапан, повний зовнішній вплив клапана, регулювання, перетворення сигналу, щьо управляє, підігрівач високого тиску.

Постановка проблеми. Одним із найважливіших параметрів ПВТ є рівень конденсату пари, що гріє. Підтримка цього параметра реалізує основну мету ПВТ - підігрів води для парогенератора. Підвищення рівня КГП в ПВТ може призвести до затоплення змійовиків i, як наслідок, потрапляння вологи в турбіну, що призведе до аварії 3 пошкодженням лопаток турбіни. Зниження рівня призводить до оголення змійовиків i, отже, до запарювання ПВТ, підвищення у ньому тиску, що може призвести до розриву.

За відсутності регенеративного підігріву живильної води досить значне відведення теплоти в холодному джерелі - конденсаторі турбіни. Частина теплоти могла б бути використана для підігріву живильної води у спеціальних регенератив- них підігрівачах перед подачею іiї в парогенеруючу установку. Для здійснення регенеративного підігріву живильної води вологий пар зі ступенів турбіни може відводитися для часткової конденсації в регенеративних підігрівачах і потім повертатися в турбіну для подальшого виконання робіт у ній.

Система регенерації високого тиску є складовою частиною системи живильної води. Відповідно до класифікації технологічних систем, обладнання та трубопроводів за впливом на безпеку за «Загальними положеннями забезпечення безпеки атомних станцій» (ОПБ), підігрівачі високого тиску відносяться до систем нормальної експлуатації, важливих для безпеки.

Контроль рівня КГП забезпечує безаварійну роботу всього блоку. Система регенерації 
високого тиску призначена для підігріву живильної води, яка подається живильними насосами 3 деаераторів у парогенератори паром, частково відпрацьованих у проточній частині головної турбіни. Застосування ПВТ підвищує ККД установки і суттєво впливає на безпеку і надійність АЕС. Група ПВД підігріває воду, яка надходить у парогенератор, зменшуючи підігрів живильної води до кипіння, і тим самим зменшує кількість енергії, яка передається першим контуром для підігріву води до стану насичення. Для запобігання аварійним ситуаціям і для правильної роботи установки необхідно регулювати рівень конденсату в ПВД шляхом регулювання РК.

Підігрівач високого тиску являє собою вертикальний апарат поверхневого типу. Основними вузлами підігрівача $є$ корпус і трубна система. Корпус складається 3 верхньої з'ємної частини і нижньої нерухомої частини.

Трубна частина складається із шести спіральних колон: трьох колекторів, що роздають, і трьох колекторів, що збирають, до яких приєднані горизонтальні змійовики, виконані у вигляді зварних спіралей. У нижній частині підігрівача до цих колекторів приєднано патрубки для підведення i відведення живильної води.

Постановка завдання. Метою статті є дослідження впливу нелінійності регулюючого клапана на перехідний процес регулювання. Також слід розглянути можливість перетворення сигналу за відомого впливу для здійснення управління з ідеалізованою залежністю між керуючим сигналом і витратою пари; змоделювати результати дослідження у середовищі Simulink. Дослідження стійкості і якості автоматичної системи регулювання має проводитися у тісному зв'язку з дослідженням iї поведінки у сталих режимах.

Виклад основного матеріалу дослідження. Аналіз - це дослідження готової автоматичної системи регулювання з метою визначення іiї властивостей і шляхів їх поліпшення. Синтез - це проєктування автоматичної системи регулювання, що задовольняє поставленим вимогам.

Синтез автоматичної системи регулювання зазвичай виконують так:

1. Вивчення об'єкта регулювання, умов його роботи та основних збурень.

2. Формулювання вимог, що пред'являються до системи автоматичного регулювання.

5. Вибір принципу регулювання та початкової схеми регулятора.

4. Вибір i розрахунок елементів регулятора та їхніх параметрів на основі вимог, що пред'являються до статичних і динамічних властивостей системи.

5. Експериментальне дослідження системи автоматичного регулювання.

Під час проєктуванні системи автоматичного регулювання рівною мірою використовуються як теоретичні, так і експериментальні методи дослідження. Застосування теоретичних методів аналізу і синтезу вимагає попереднього математичного опису системи автоматичного регулювання. Як об'єкт управління розглядається група ПВТ.

Основним регулюючим органом у подібних системах виступає регулюючий клапан. Незалежно від конструктивного виконання кінцевою метою підбору клапана $є$ забезпечення лінійної залежності між регулюючим впливом і зміною регульованого параметра.

Регулюючі клапани (РК) підігрівачів системи регенерації призначені для регулювання рівня конденсату пари, що гріє в паровому просторі корпусу підігрівачів високого тиску (ПВТ), шляхом часткового відкриття або закриття клапана у статичних і динамічних режимах роботи турбоустановки.

Для захисту турбіни від попадання води і захисту корпусу підігрівача високого тиску від руйнування у разі перевищення рівня конденсату вище допустимого (у результаті розриву труб, появи свищів у місцях зварювання елементів трубної системи та інших причин) усі підігрівачі високого тиску оснащують груповим захисним пристроєм від переповнення.

Як виконавчий орган захисту від підвищення рівня в підігрівачі високого тиску використовують автоматичний пристрій зі швидкодіючими впускним і зворотним клапанами.

Впускний клапан із виносним гідроприводом i зворотний клапан, надпоршневі порожнини яких з'єднані між собою перепускними трубами, $\epsilon$ основними елементами захисту.

Підставою для конструювання РУПВД служать дані гідравлічного розрахунку. РК підігрівачів високого тиску призначені для регулювання рівня конденсату пари, що гріє у паровому просторі корпусу підігрівача високого тиску, шляхом відкриття або закриття клапана. Особливістю РК $\epsilon$ робота на скипати потоці, що призводить до інтенсивного ерозійного зносу проточної частини і корпусу клапана, а також супроводжується кавітацією, шумом, вібрацією, які знижують довговічність і надійність арматури. Впускний клапан установлюється на трубопроводі живильної води на вході у підігрівач високого тиску і призначений для аварійного відключення подачі живиль- 
ної води у підігрівач високого тиску і перепуску iii в живильний трубопровід по байпасних лініях, минаючи підігрівач високого тиску.

Клапани на трубопроводі встановлюються у строго вертикальному положенні.

Стабільне управління теплообмінним приладом, наприклад, отримують за лінійної залежності його теплового потоку від ходу штока регулюючого клапана. Із цією метою розглядають ідеальну спільну роботу теплообмінного приладу i регулюючого клапана. Ї̈ї суть полягає у тому, що видаткова характеристика клапана повинна бути дзеркальним відображенням характеристики теплообмінного приладу (рис. 1).

Однак зміна витрати пари клапаном залежить як від його пропускної здатності, так і від ділянки системи, на якій клапан викликає зміну тиску пари. Лінійні або логарифмічні витратні характеристики справедливі за повного зовнішнього впливу клапана а $1+=$ (тиск регульованої ділянки втрачається в регулюючому отворі). Однак дана характеристика спотворюється зі зменшенням впливу клапана. Чим менше вплив, тим більше кривизна видаткової характеристики, тобто більш значним є розрегулювання системи. У системах регулювання цей параметр у проєктуванні систем управління не враховують, хоча він значно впливає на якість регулювання і тому повинен бути врахований під час розрахунку керуючого впливу, щоб наблизити перехідний процес регулювання до ідеалізованого. Розглянемо лінійні і логарифмічні витратні характеристики 3 урахуванням впливу клапана: відносне положення клапана $\mathrm{h} /$ h100 є функцією керуючого сигналу для того, щоб домогтися, щоб відносна витрата лінійно залежала від керуючого сигналу (наприклад, сигналу за напругою).

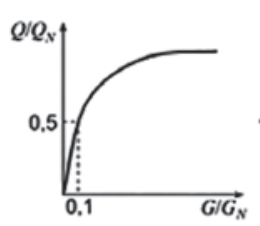

a

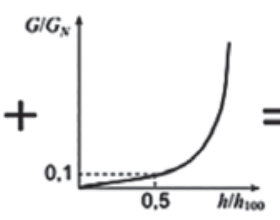

6

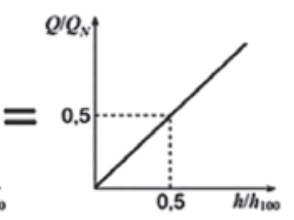

B
Рис. 1. Регулювання теплообмінного приладу (а - характеристика теплообмінного приладу; б - видаткова характеристика регулювання теплообмінного приладу; в - ідеальна характеристика регулювання теплообмінного приладу)

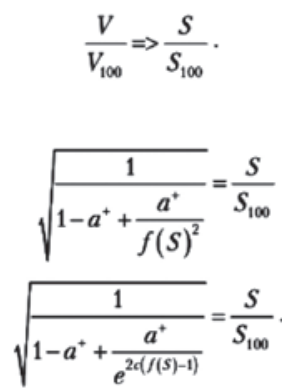

$f(S)=\sqrt{\frac{1}{1-\frac{1}{a^{+}}+\frac{1}{\left(\frac{S}{S_{100}}\right)^{2} a^{+}}}}$

Після перетворень отримуємо функцію $\mathrm{f}(\mathrm{S})$, яка коригує керуючий сигнал на регулюючий клапан. Для перевірки ефективності даного перетворення було створено модель (рис. 4) групи підігрівачів високого тиску в середовищі Simulink. На підставі цієї моделі порівнюється процес регулювання 3 даними перетворенням і без нього. Як обурюючий сигнал використовується витрата пари. Регульований параметр - рівень у ПВТ. Клапан був вибраний лінійний. Із графіка (рис. 5) видно, що регулювання із запропонованим перетворенням відбувається якісніше й однаково за всіх збурень, оскільки залежність залишається лінійною за будь-якого положення клапана. Інтегральний критерій якості

$$
J_{i}=\int_{0}^{+\infty}|\varepsilon| d t
$$

дорівнював

$$
J_{0}=3005 \text { и } J_{1}=2553
$$

для моделі без перетворення сигналу і з ним відповідно, що показує підвищення якості (згідно iз цим критерієм) на $17,7 \%$. Окрім цього, у процесі регулювання клапан рухається значно менше (рис. 6), що підвищує надійність даного елемента.

Висновки. Отримано формули, що дають змогу перетворювати керуючий сигнал для вирівнювання видаткової (лінійної і логарифмічної) характеристики клапана. Їх ефективність була перевірена на моделі групи підігрівачів високого тиску, розробленої в середовищі Simulink.

Чисельний експеримент показав, що дане перетворення:

1) може значно підвищити якість регулювання процесу, що передбачає наявність регулюючого клапана;

2) знижує знос виконавчого механізму;

3) особливо ефективне у сфері роботи клапана, де видаткова характеристика має велику крутизну. 
$\frac{V}{V_{100}}=\sqrt{\frac{1}{1-a^{+}+\frac{a^{+}}{\left(h / h_{100}\right)^{2}}}}$

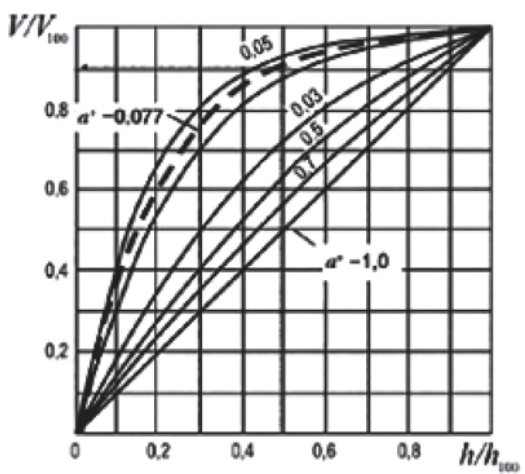

Рис. 2. Лінійна видаткова характеристика клапана
$\frac{V}{V_{100}}=\sqrt{\frac{1}{1-a^{+}+\frac{a^{+}}{e^{2 c\left(h / h_{100}-1\right)}}}}$



Рис. 3. Логарифмічна видаткова характеристика клапана

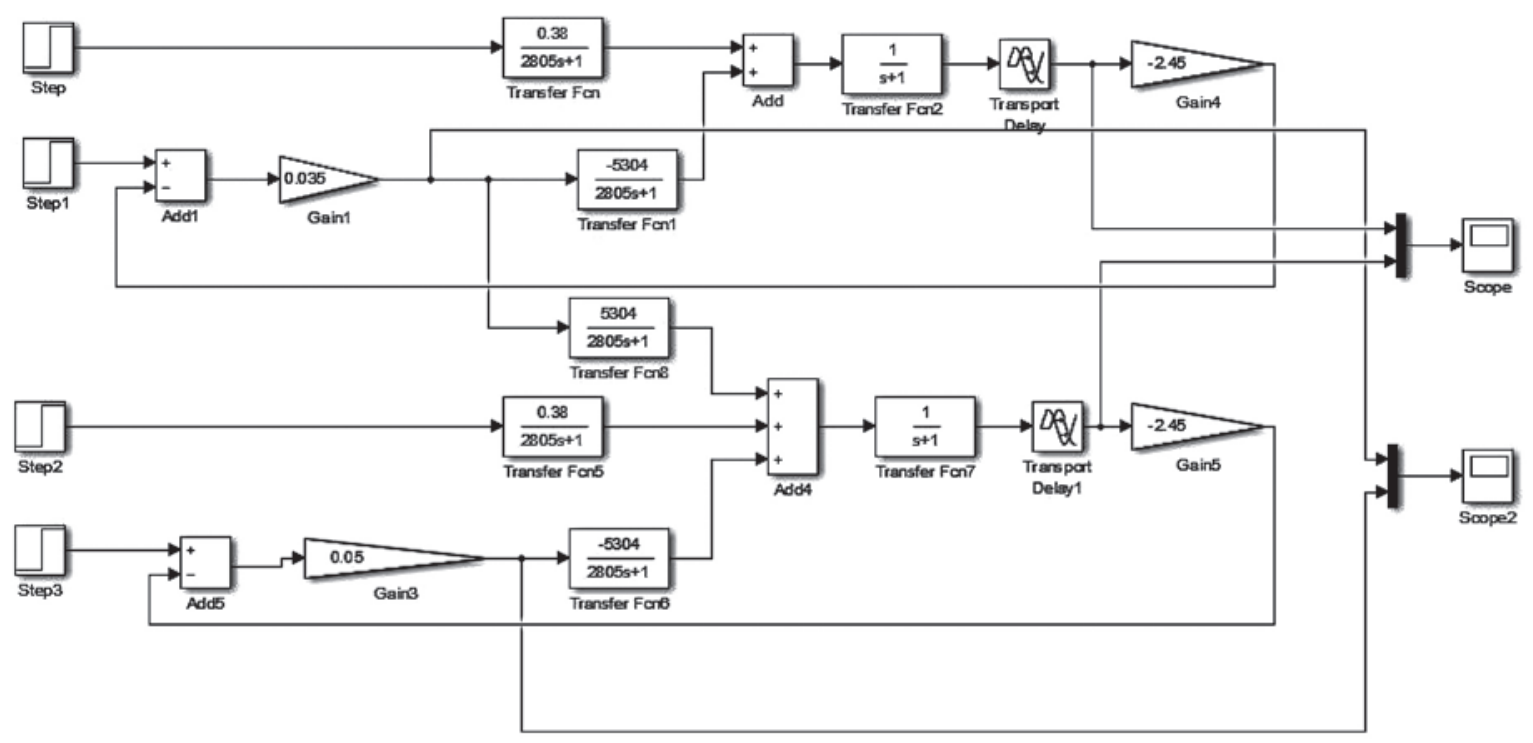

Рис. 4. Моделювання перетворення керуючого впливу в Simulink

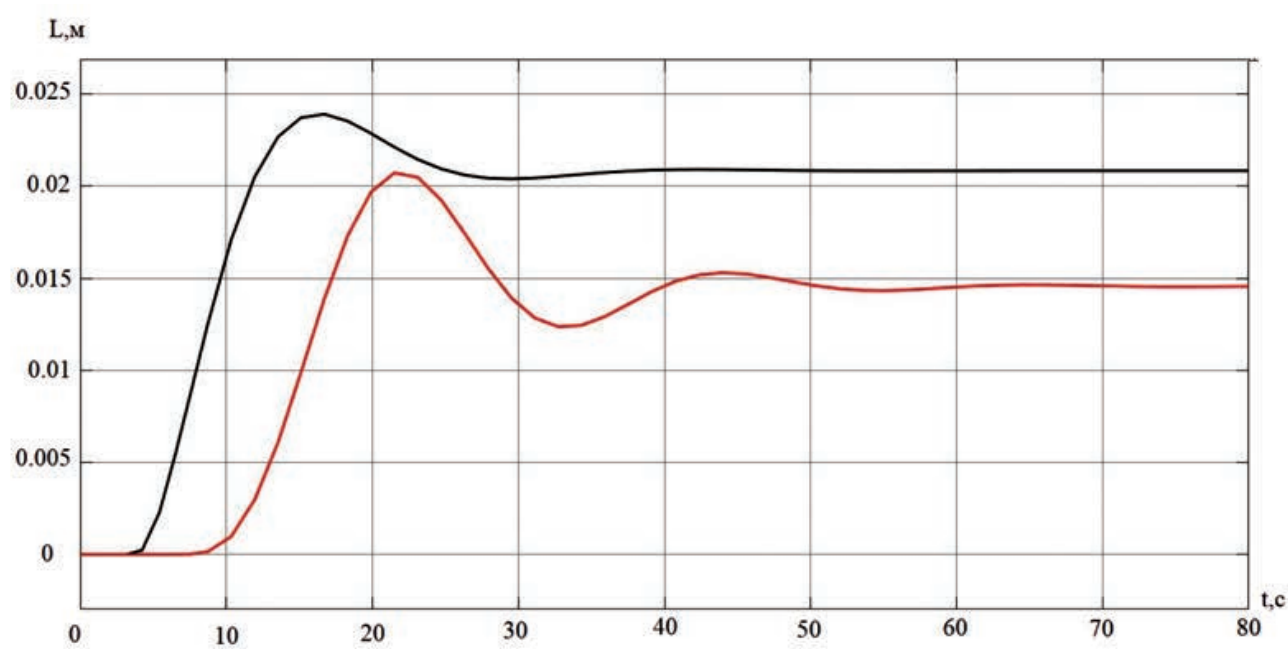

Рис. 5. Перехідний процес регулювання 


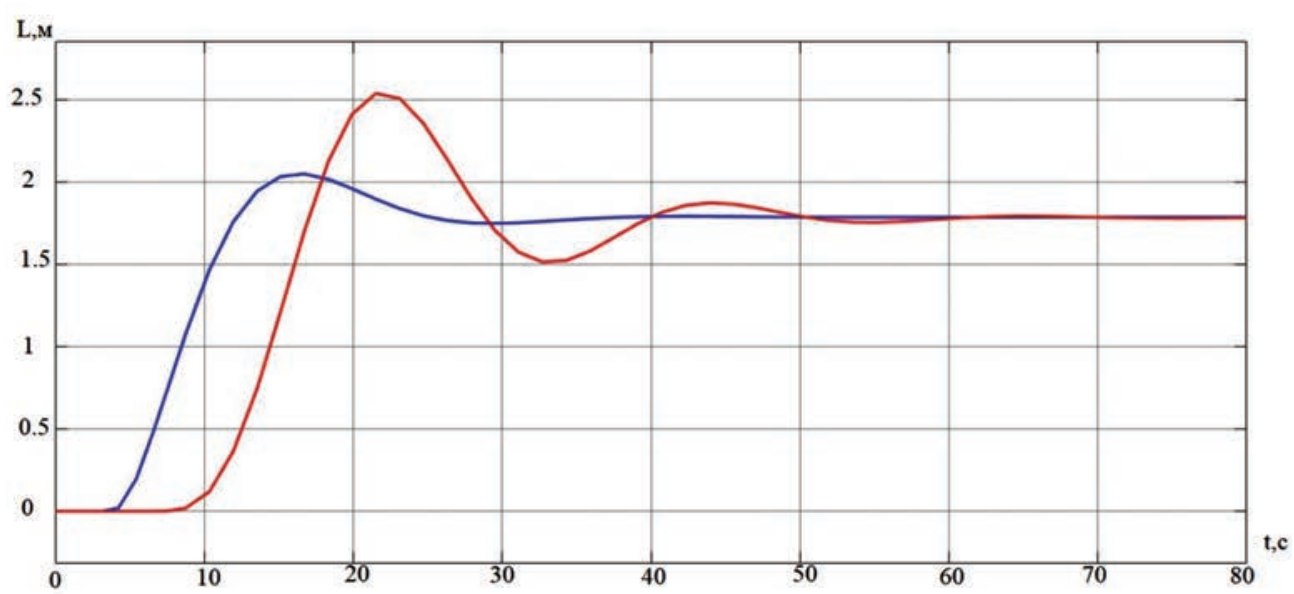

Рис. 6. Рух клапана в процесі регулювання

\section{Список літератури:}

1. Коміссарчик В.Ф. Автоматичне регулювання технологічних процесів : навчальний посібник. Твер : ТНТУ, 2001. С. 27-29.

2. Преображенський В.П. Теплотехнічні вимірювання та прилади : підручник ; 3-є вид., перероб. Москва : Енергія, 1978. С. 35-40.

3. Демченко В.А. Автоматизація і моделювання технологічних процесів АЕС і TЕС. Одеса : Асторпрінт, 2001.

4. Клюєв А.С., Глазов Б.В., Дубровський А.Х. Проєктування систем автоматизації технологічних процесів. Москва : Вища школа, 1990.

5. Максимов М.В. Метод оцінки ефективності алгоритму маневру потужністю енергоблоки з реакторами ВВЕР-1000. Вісник вузів. Серія «Ядерна енергетика». 2008. Вип. 4. С. 128-139.

6. Баскаков В.С. Алгоритм експлуатації енергоблоку з ВВЕР у підтримці добового балансу потужності енергосистеми. Пращ̧і Одеського політехнічного університету. 2007. Вип. 2(28). С. 56-59.

7. Сучасні технології управління : монографія : у 2-х т. / за заг. ред. С.В. Купрієнко. Одеса : Купрієнко С.В., 2012. 179 с.

8. Медведєв Р.Б., Сангінова А.В. Оптимальне керування процесом зміни концентрації борної кислоти в теплоносії першого контуру AEC з BВEР-1000. Науковий вісник Національного технічного університету України «Київський політехнічний інститут». 2002. Вип. 2(22). С. 29-56.

9. Волошкіна А.А., Бєглов К.В., Плахотнюк А.А. Дослідження регулятора концентрації рідкого поглинача енергоблоку АЕС. Автоматизація технологічних і бізнес-процесів. 2015. Т. 7. Вип. 4. С. 18-24.

\section{Malovichko V.K., Brunetkin O.I. INVESTIGATION OF AUTOMATIC WATER LEVEL REGULATION SYSTEM IN THE GROUP OF HIGH PRESSURE HEATERS}

The high pressure regeneration system is an integral part of the feed water system. According to the classification of technological systems, equipment and pipelines according to the impact on safety according to the "General provisions for the safety of nuclear power plants" $(O P B)$, high pressure heaters are systems of normal operation that are important for safety.

Control of the level of KGP ensures trouble-free operation of the whole unit. The high-pressure regeneration system is designed to heat the feed water supplied by feed pumps from deaerators to steam steam generators, partially spent in the flow part of the main turbine. The use of HTP increases the efficiency of the installation and significantly affects the safety and reliability of NPPS. The LDPE group heats the water entering the steam generator, reducing the heating of the feed water to boiling, and thus reduces the amount of energy transmitted by the first circuit to heat the water to saturation. To prevent accidents and for the proper operation of the installation, it is necessary to adjust the condensate level in the LDPE by adjusting the LCD.

The high pressure heater is a vertical surface type apparatus. The main components of the heater are the housing and piping system. The body consists of an upper ground part and a lower fixed part.

The pipe part consists of six spiral columns: three are distributed and three collect collectors to which the horizontal coils executed in the form of welded spirals are connected. In the lower part of the heater to these collectors branch pipes for supply and drainage of feed water are connected. The use of HTP increases the CCT of the installation and significantly affects the safety and reliability of NPPs. To 
prevent accidents and for proper operation of the unit, it is necessary to adjust the condensate level in the HTP by adjusting the water level.

The influence of the regulating valve on the transient process of regulation is investigated. The conversion of the signal controlling the level in the high pressure heater is found. An experiment was performed on a model of a heating point in the Simulink environment. The results of the experiment are analyzed.

Key words: control valve, full external influence of the valve, regulation, conversion of the control signal, high pressure heater. 